\title{
Stress relaxation in samples made of acrylonitrile butadiene styrene material manufactured by fused deposition modelling
}

\author{
Relaksacja naprężeń w próbkach wykonanych \\ z akrylonitrylu-butadienu-styrenu \\ wytworzonych metodą FDM
}

Increased interest in fused deposition modeling (FDM) resulting, for example, from its use in the production of utility models determines the undertaking of research on mechanical and rheological properties of materials. Mechanical and rheological properties of models made of materials used in FDM technology depend on technological parameters. In this paper, the effect of $0^{\circ}$ and $90^{\circ}$ print orientation on stress relaxation was analyzed. Additionally, the usefulness of the rheological model to describe the relaxation curve was evaluated. Stress relaxation tests were performed by tensile testing. The five-parameter Maxwell-Wiechert model was used to describe stress relaxation. The tests showed little effect of print orientation on the rheological parameters of the five-parameter model. The Maxwell-Wiechert model showed a very good approximation to the stress relaxation curves.

KEYWORDS: stress relaxation, ABS, FDM technology, 3D printing

Wzrost zainteresowania technologią osadzania topionego materiału (FDM), wynikający m.in. z zastosowania jej do produkcji modeli użytkowych, wymusza podjęcie badań nad właściwościami mechanicznymi w tym reologicznymi materiałów. Właściwości mechaniczne (i reologiczne) modeli wytwarzanych z materiałów stosowanych w technologii FDM zależą od parametrów technologicznych. W prezentowanym artykule poddano analizie wpływ orientacji wydruku $0^{\circ}$ i $90^{\circ}$ na relaksację naprężeń. Dodatkowo oceniono przydatność modelu reologicznego do opisu krzywej relaksacji. Testy relaksacji naprężeń wykonano poprzez próbę rozciągania. Do opisu relaksacji naprężeń zastosowano pięcioparametrowy model Maxwella-Wiecherta. Badania wykazały niewielki wpływ orientacji wydruku na parametry reologiczne modelu pięcioparametrowego. Model Maxwella-Wiecherta wykazał bardzo dobrą aproksymację do krzywych relaksacji naprężeń.

SŁOWA KLUCZOWE: relaksacja naprężeń, ABS, technologia FDM, druk 3D

\section{Introduction}

Fused deposition modeling (FDM) is one of the most popular methods in 3D printing. The popularity is due to the availability of cheap and biodegradable materials, as well as the low cost of manufacturing a model using this technology $[1,2]$. Due to its popularity, FDM technology has found a wide range of applications use in various sectors of production [1]. In the paper [3] applied fused deposition modelling technologies in the foundry industry to manufacturing mold and casting models. The article [4] shows the use of FDM technology in improving the areodymium of a wing section by printing ribs using this technology. One of the most used materials in fused deposition technology is acrylonitrile butadiene styrene (ABS). ABS material has good strength properties and can be used for example to produce car bumpers and pillars [5].

Several publications focus on the study of mechanical properties of models manufactured in FDM technology [2, 6-9]. The mechanical properties of models produced by fused deposition modeling are determined by the technological parameters of the printing process. In the article [7] results of research on the influence of raster angles $0^{\circ}$ and $90^{\circ}$ on the mechanical properties of models made in FDM technology of ABS material. The results shown that these raster angles achieved the highest strengths of: $30.8 \mathrm{MPa}$ and $2050 \mathrm{MPa}$. The paper [10] shows research on the influence of raster angles of $0^{\circ}, 45^{\circ}, 90^{\circ}$, and layer thicknesses of $0.2 ; 0.3$; $0.4 \mathrm{~mm}$ on the mechanical properties of models printed using FDM technology with polyether-ether-ketone (PEEK) and acrylonitrile butadiene styrene (ABS) materials. The research showed that tensile, compressive and flexural strengths of PEEK samples were higher in comparison with ABS samples by $108 \%, 114 \%$ and $115 \%$, respectively. Optimal mechanical properties of PEEK material were obtained for layer thickness $0.3 \mathrm{~mm}$ and raster angles of $0^{\circ}, 90^{\circ}$.

The study of rheological properties is often wrongly neglected. In the case of products that will be working under permanent load, but also in the case of all kinds of connections that ensure tightness, it is necessary to carry out research in this direction [11]. The article [12] shows rheological properties of samples produced by selective laser sintering (SLS) technology of polymer-aluminum composites. Stress relaxation tests were performed for the material. The specimens were printed at three print angles $X, Y, Z$. Five-parameter Maxwell-Wiechert models were used to describe the relaxation curves, the use of which

\footnotetext{
* Mgr inż. Wiktor Szot, wszot@tu.kielce.pl, https://orcid.org/0000-0001-9512-9680 - Faculty of Mechatronics and Mechanical
} Engineering, Kielce University of Technology, Kielce, Poland 
has been extensively described in papers [13-15] among others. The study showed that there is no difference in the print directions for stress relaxation.

The aim of the research presented in this paper is to assess the influence of the printing angles: $0^{\circ}$ and $90^{\circ}$ of the models manufactured in the FDM technology of the ABS material on the elastic modulus and dynamic viscosity coefficients.

\section{Materials and methods}

The samples were produced on a Dimension BST 1200 es 3D printer. The 3D printer uses fused deposition modelling (FDM) (fig. 1). FDM technology is based on applying layer by layer of polymer or polymer-based composite material on the working platform of the $3 \mathrm{D}$ printer by means of nozzles $[13,14]$. The print head heats the material to its melting point and moves in the $O X$ and $O Y$ directions $[13,14]$. The work platform moves in the $O Z$ direction. The Dimension BST 1200es 3D printer uses two print nozzles, one for model material and the other for soluble or breakable support material. The work table measures $254 \times 254 \times 305 \mathrm{~mm}$ and is heated to $100^{\circ} \mathrm{C}$. In addition, the $3 \mathrm{D}$ printer is enclosed and the work chamber is heated to $200^{\circ} \mathrm{C}$. The printer has a software CatalystEX preparing files for printing. The most commonly used materials for FDM technology printing are acrylonitrile butadiene styrene (ABS) and polylactic (PLA).

The samples were designed in SolidWorks according to ISO 527 and saved in the format: .stl (fig. 2). The parameters for saving the .st file: deviation $0.006 \mathrm{~mm}$, angle $5^{\circ}$ and number of triangles created 204 .

The .stl files were prepared for printing in CatalyxEX printer software. A total of 20 samples were printed. The technological parameters used for the printing were layer thickness: $0.254 \mathrm{~mm}$ and infil type: high

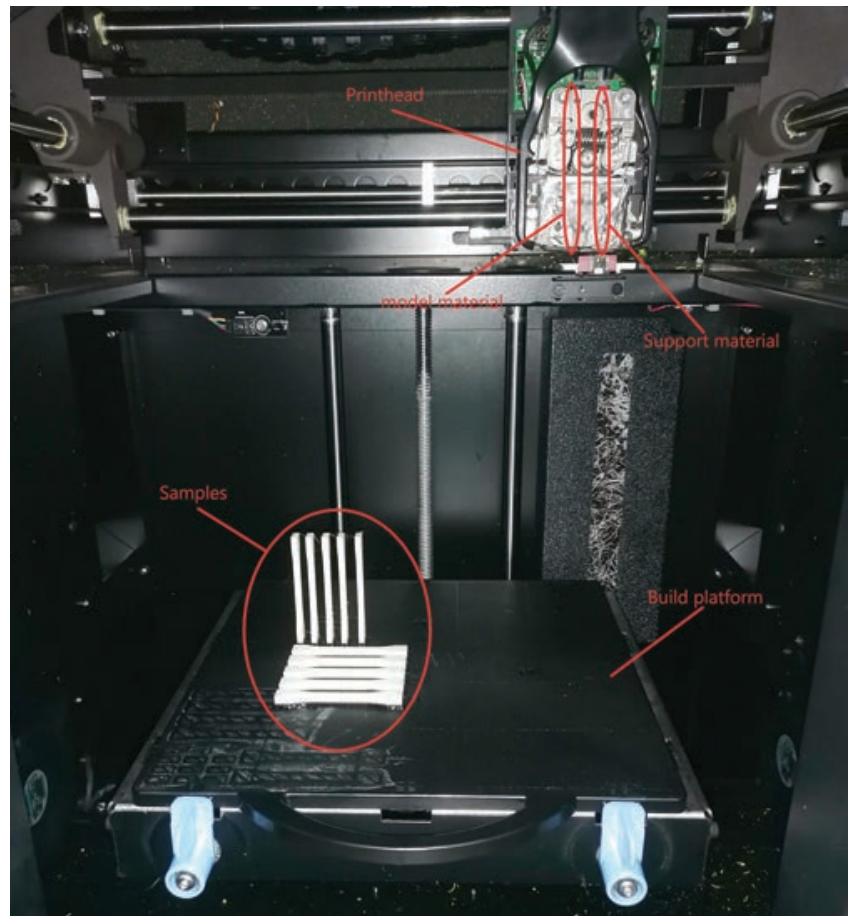

Fig. 1. Schematic working principle of FDM technology

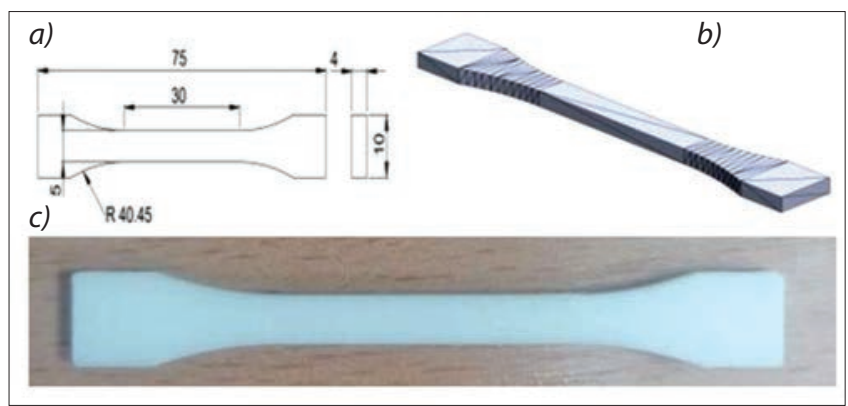

Fig. 2. ISO 527 Sample: $a$ ) dimension, $b$ ) .st/ file, c) printed

density for all samples. The changing technological parameter was the positioning on the printer work platform. Ten samples were positioned at an angle: $0^{\circ}$ and the other as the same number at $90^{\circ}$ (fig. 3).

The specimens were manufactured from ABS material. Table I shows selected properties of the ABS material as specified by Stratasys corporation.

\section{TABLE I. Properties of ABS material}

\begin{tabular}{|c|c|c|}
\hline Properties & Standard & Value \\
\hline Young Moduls & ASTM D638 & $2200 \mathrm{MPa}$ \\
\hline $\begin{array}{c}\text { Tensil Strength, } \\
\text { ultimate }\end{array}$ & ASTM D638 & $33 \mathrm{MPa}$ \\
\hline $\begin{array}{c}\text { IZOD Impackt } \\
\text { (method A) }\end{array}$ & ASTM D256 & $106 \mathrm{~J} / \mathrm{m}$ \\
\hline Rocwell Hardness & ASTM D785 & 109.5 \\
\hline
\end{tabular}

The relaxation tests were performed on an Inspekt Mini strenght machine (maximum load of $3 \mathrm{kN}$ ). The relaxation test was performed by tensile testing (fig. 4).

The samples were stretched at a rate of $15 \mathrm{~mm} /$ min to a specified strain of $1.5 \mathrm{~mm}$. The test strain was then recorded over a period of 600 seconds. The test parameters were determined by testing additional samples. The data and graphs from the recoil tests recorded by the LabMaster software included with the test machine were processed in OriginPro to

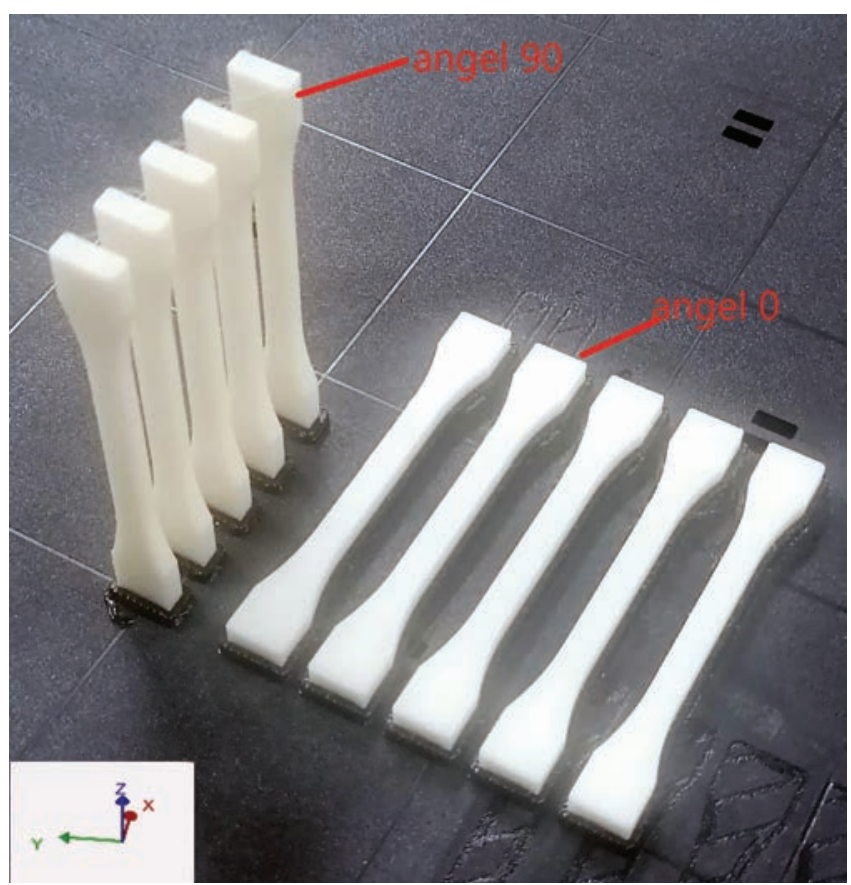

Fig. 3. Place samples on the 3D printer work platform 


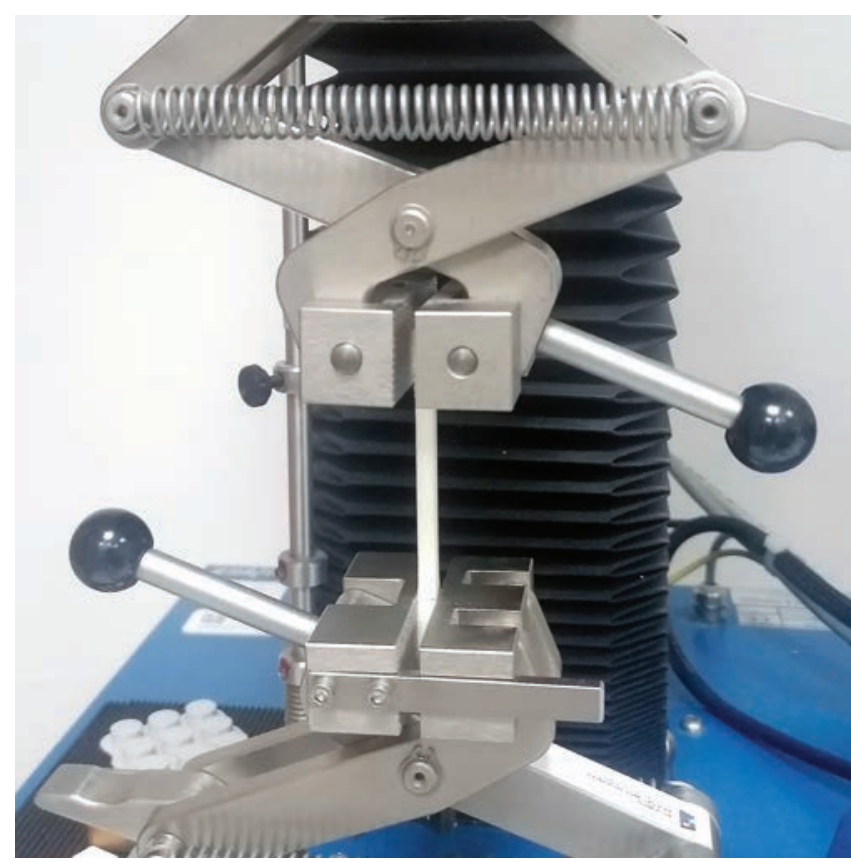

Fig. 4. Tensile tests of ISO 527 specimens of ABS material

produce a relaxation curve. The five-parameter Maxwell-Wiechert model [15] (fig. 5) of equation (1) was used to describe the relaxation curve:

$$
\sigma(t)=\sigma_{0}+\sigma_{1} e^{\frac{-t}{t_{1}}}+\sigma_{1} e^{\frac{-t}{t_{2}}}
$$

where: $-t_{1}, t_{2}$ - time relaxation, $\sigma_{0}, \sigma_{1}, \sigma_{2}$ - partial stresses.

In OriginPro, the Levenberg-Marquardt method is used to approximate the test data with an exponential function. The accuracy of the fit is estimated from the coefficients of $\chi^{2}$ and $C h i^{2}$.

The function (1) is the response to a given step strain in the relapse test (2) for the material:

$$
\sigma(t)=\varepsilon 0 \mathrm{H}(t)
$$

where: $\mathrm{H}(t)$ - function Heaviside'a $\varepsilon 0$ - determined strain in relaxation test.

The five-parameter Maxwell-Wiechert model can still be written using the function (3) taking into account the elastic moduli and dynamic viscosity coefficients:

$$
\sigma(t)=\varepsilon_{0}\left(E_{0}+E_{1} e^{\frac{-E_{1} t}{\eta_{1}}}+E_{2} e^{\frac{-E_{2} t}{\eta_{2}}}\right)
$$

where: $E_{0}, E_{1}, E_{2}$ - elastic moduli, $\eta_{1}, \eta_{2}$ - dynamic viscosity coefficients.

In addition, for each of the partial stresses and relaxation times, the mean variance, standard deviation, and Type A measurement uncertainty were calculated from equation (4):

$$
u_{A}=\sqrt{\frac{1}{n(n-1)} \sum_{i=1}^{n}\left(x_{i}-\bar{x}\right)^{2}}
$$

where: $x_{\mathrm{i}}$ - value of the $\mathrm{i}$-th measurement, $\bar{x}$ - average, $n$ - number of measurements.
Fig. 5. The five-parameter Maxwell-Wiechert model

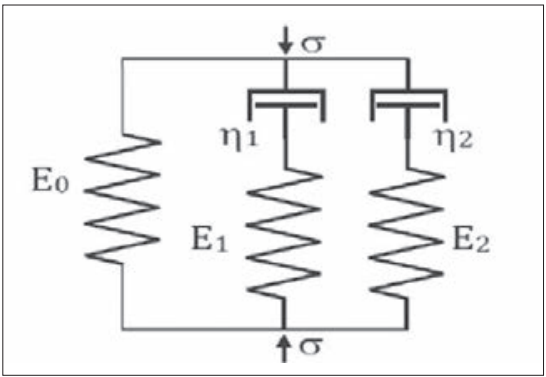

The equivalent modulus was calculated from the equation (5):

$$
E_{s}=E_{0}+E_{1}+E_{2}
$$

where: $E_{0}, E_{1}, E_{2}$ - modulus of elasticity.

\section{Results}

Tables II and III show the parameter results of the fitted stress relaxation curves in ABS material for $0^{\circ}$ and $90^{\circ}$ specimens, respectively. The tables also include the coefficients $R^{2}$ and $C h i^{2}$ which are used to evaluate the qualitative fit of the relaxation curve to the rheological model, the mean values $\bar{X}$, the standard deviation $s$, and the uncertainty of the approximation $u_{\mathrm{A}}$.

The low values of standard deviation $s$ and uncertainty of approximation $u_{\mathrm{A}}$ can be observed in table II.

It is also worth noting that the coefficient $\mathrm{Chi}^{2}$ reaches values close to zero, which indicates a very good quality of fit. The coefficient $R^{2}$ has values close to 1 , which also indicates a very good quality of the fit of the rheological model to the relaxation curve.

Table III shows that $R^{2}$ also has values close to 1 as in the table I, which indicates a very good fit. The coefficient $C h i^{2}$ has values close to 0 , which indicates a very

\begin{tabular}{|c|c|c|c|c|c|c|c|}
\hline Sample & $\begin{array}{c}\sigma_{0} \\
{[\mathrm{MPa}]}\end{array}$ & $\begin{array}{c}\sigma_{1} \\
{[\mathrm{MPa}]}\end{array}$ & $\begin{array}{c}\sigma_{2} \\
{[\mathrm{MPa}]}\end{array}$ & $\begin{array}{c}t_{1} \\
{[\mathrm{~s}]}\end{array}$ & $\begin{array}{c}t_{2} \\
{[\mathrm{~s}]}\end{array}$ & $C h i^{2}$ & $R^{2}$ \\
\hline 1 & 10.348 & 2.487 & 1.037 & 9.6 & 198.5 & 0.00068 & 0.9937 \\
\hline 2 & 11.215 & 2.306 & 1.062 & 10.2 & 207.1 & 0.00063 & 0.9943 \\
\hline 3 & 11.468 & 2.307 & 1.013 & 9.9 & 196.6 & 0.00061 & 0.9940 \\
\hline 4 & 11.661 & 2.086 & 0.931 & 10.2 & 207.8 & 0.00048 & 0.9944 \\
\hline 5 & 10.752 & 2.266 & 0.939 & 9,7 & 196,3 & 0.00057 & 0.9935 \\
\hline 6 & 10.418 & 2.208 & 0.973 & 9.8 & 199.4 & 0.00055 & 0.9941 \\
\hline 7 & 12.451 & 2.120 & 1.020 & 10.7 & 220.6 & 0.00054 & 0.9947 \\
\hline 8 & 9.818 & 2.682 & 1.112 & 9.4 & 188.4 & 0.00078 & 0.9937 \\
\hline 9 & 10.318 & 2.303 & 0.927 & 9.5 & 215.3 & 0.00058 & 0.9932 \\
\hline 10 & 10.245 & 2.570 & 0.986 & 9.1 & 195.6 & 0.00058 & 0.9939 \\
\hline $\bar{X}$ & 10.869 & 2.333 & 1.000 & 9.8 & 202.5 & & \\
\hline s & 0.809 & 0.192 & 0.061 & 0.459 & 9.929 & & \\
\hline$u_{\mathrm{A}}$ & 0.256 & 0.061 & 0.019 & 0.1 & 3.1 & & \\
\hline
\end{tabular}
good fit. The standard deviation $s$ and uncertainty of approximation have low values.

TABLE II. Fitting parameters for ABS stress relaxation curves angle $0^{\circ}$ 
TABLE III. Fitting parameters for ABS stress relaxation curves angle $90^{\circ}$

\begin{tabular}{|c|c|c|c|c|c|c|c|}
\hline Sample & $\begin{array}{c}\sigma_{0} \\
{[\mathrm{MPa}]}\end{array}$ & $\begin{array}{c}\sigma_{1} \\
{[\mathrm{MPa}]}\end{array}$ & $\begin{array}{c}\sigma_{2} \\
{[\mathrm{MPa}]}\end{array}$ & $\begin{array}{c}t_{1} \\
{[\mathrm{~s}]}\end{array}$ & $\begin{array}{c}t_{2} \\
{[\mathrm{~s}]}\end{array}$ & $C h i^{2}$ & $R^{2}$ \\
\hline 1 & 9.1825 & 2.4029 & 0.9314 & 8.6 & 171.4 & 0.00051 & 0.9939 \\
\hline 2 & 7075 & 2.3322 & 0.9384 & 9.7 & 200.6 & 0.00062 & 0.993 \\
\hline 3 & 10.4902 & 2.0314 & 1.0135 & 11.4 & 207.9 & 0.00044 & 0.9956 \\
\hline 4 & 10.7974 & 2.4860 & 1.0747 & 9.5 & 183.7 & 0.00065 & 0.9942 \\
\hline 5 & 9.7817 & 2.5052 & 1.0117 & 9.1 & 182.8 & 0.00063 & 0.9937 \\
\hline 6 & 10.0581 & 2.6006 & 1.0058 & 9.0 & 197.3 & 0.00068 & 0.9932 \\
\hline 7 & 10.0938 & 2.4478 & 0.9999 & 9.8 & 217.1 & 0.00071 & 0.9929 \\
\hline 8 & 10.6428 & 2.5639 & 1.1997 & 10.0 & 205.6 & 0.00081 & 0.9942 \\
\hline 9 & 10.2836 & 2.5273 & 1.0886 & 9.6 & 219.4 & 0.00076 & 0.9933 \\
\hline 10 & 11.1647 & 2.5853 & 1.1772 & 9.9 & 212.7 & 0.00077 & 0.9943 \\
\hline $\bar{X}$ & 10.220 & 2.448 & 1.044 & 9.7 & 199.8 & & \\
\hline $\mathrm{s}$ & 0.583 & 0.169 & 0.091 & 0.754 & 16.018 & & \\
\hline$u_{\mathrm{A}}$ & 0.184 & 0.053 & 0.029 & 0.2 & 5.1 & & \\
\hline
\end{tabular}

Figure 6 shows the stress relaxation curves in ABS material. On the left side the curve for the angle of $90^{\circ}$ and on the right side for the angle of printing: $0^{\circ}$.

The initial analysis of the obtained curves shows that for the printing angle of $0^{\circ}$ higher specific stresses are obtained than for the printing angle of $90^{\circ}$. Example approximations of the experimental curves with equation (2), as well as with the parameters and coefficients of the qualitative evaluation of the fit are shown in figs. 7 and 8.
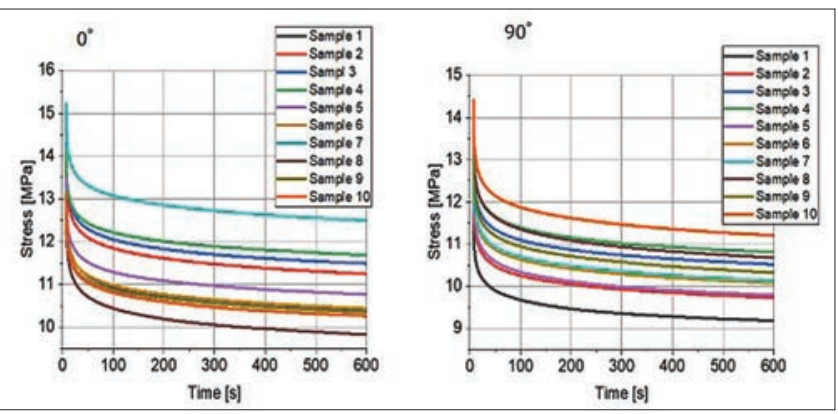

Fig. 6. Experimental stress curves

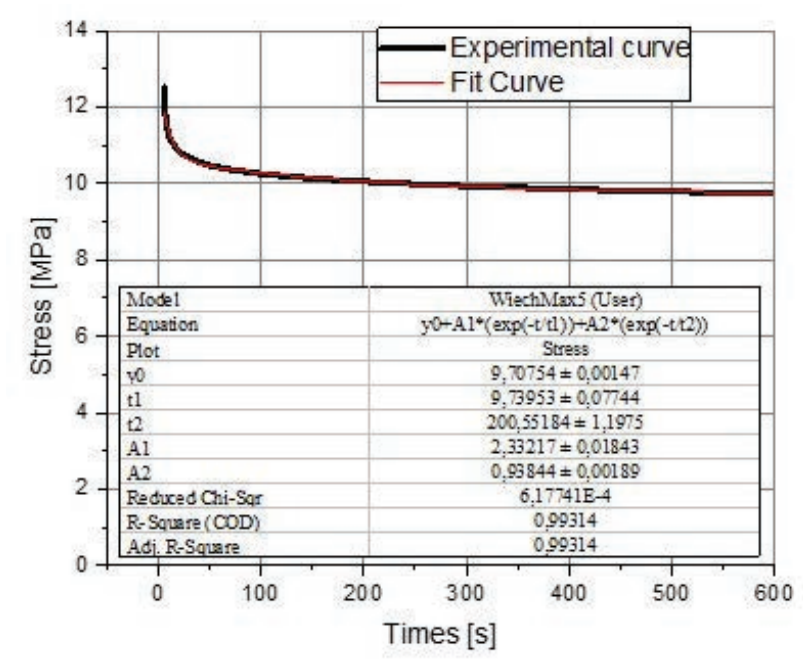

Fig. 7. Fitting a five-parameter Maxwell-Viechert model to an experimental relaxation curve. Print angle of $90^{\circ}$

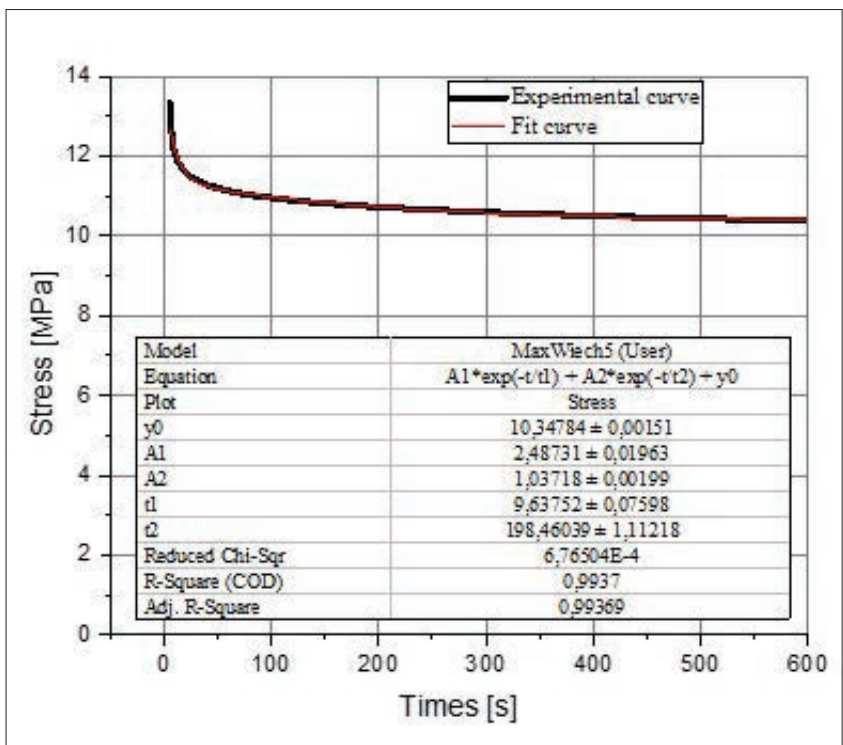

Fig. 8. Fitting a five-parameter Maxwell-Viechert model to an experimental relaxation curve. Print angle of $0^{\circ}$

Analyzing figs. 7 and 8 visually, one can see a satisfactory fit between the curve describing the five-parameter Maxwell-Wiechert model (red) and the experimental curve (black). Based on equations (1) and (3) and the average values of stress $\bar{\sigma}$, relaxation time $\bar{t}$ shown in tables II and III and $\varepsilon 0=0.03$ the moduli of elasticity and coefficients of dynamic viscosity were calculated. The calculated values of elastic moduli and dynamic viscosity are presented in table IV.

\section{TABLE IV. Parameters of the rheological models}

\begin{tabular}{|c|c|c|c|c|c|c|}
\hline Angel & $\begin{array}{c}E_{0} \\
{[\mathrm{MPa}]}\end{array}$ & $\begin{array}{c}E_{1} \\
{[\mathrm{MPa}]}\end{array}$ & $\begin{array}{c}E_{2} \\
{[\mathrm{MPa}]}\end{array}$ & $\begin{array}{c}\eta_{1} \\
{[\mathrm{Mpa} \cdot \mathrm{s}]}\end{array}$ & $\begin{array}{c}\eta_{2} \\
{[\mathrm{Mpa} \cdot \mathrm{s}]}\end{array}$ & $\begin{array}{c}E_{\mathrm{s}} \\
{[\mathrm{Mpa}]}\end{array}$ \\
\hline $0^{\circ}$ & 362.31 & 77.78 & 33.33 & 763.845 & 6751.843 & 473.42 \\
\hline $90^{\circ}$ & 340.67 & 81.61 & 34.80 & 789.333 & 6955.113 & 457.08 \\
\hline
\end{tabular}

Based on table IV, it can be seen that the equivalent modulus for the $0^{\circ}$ print orientation is $3.5 \%$ greater than the $90^{\circ}$ print orientation. The dynamic viscosity coefficient $\eta_{1}$ for the $90^{\circ}$ print orientation is $3.2 \%$ greater than for the $0^{\circ}$ print orientation. The dynamic viscosity coefficient $\eta_{2}$ for a print orientation of $90^{\circ}$ is greater by $3 \%$ than for $0^{\circ}$ orientation.

\section{Conclusion}

The ideal body model allows describing the real-time behavior of the material under a given deformation. The very low values of standard deviations and measurement uncertainties for each parameter of the Maxwell-Wiechert model show a very good fit. Also the very low values for $\mathrm{Chi}^{2}$ and values close to 1 for $R^{2}$ indicate a very good approximation. Therefore, the choice of the Maxwell-Wiechert five-parameter model proved to be appropriate.

The results showed that the print orientation does not have a big influence on the rheological parameters, in the case of ABS material formed incrementally by FDM technology using Dimension BST 1200e $3 \mathrm{D}$ printer. The differences in values oscillate at $3 \%$. 


\section{REFERENCES}

[1] Suárez L., Domínguez M. "Sustainability and environmental impact of fused deposition modelling (FDM) technologies". Int. J. Adv. Manuf. Technol. 106 (2020): 1267-1279, https://doi.org/10.1007/S00170-019-04676-0.

[2] Górski F., Kuczko W., Wichniarek R., Hamrol A. "Mechanical properties of composite parts manufactured in FDM technology". Rapid Prototyp. J. 24 (2018): 1281-1287, https://doi.org/10.1108/RPJ-11-2016-0197.

[3] Balyakin A.V., Vdovin R.A., Kyarimov R.R. "Study of FDM technology applications in the casting production of GTE details". IOP Conf. Ser. Mater. Sci. Eng. 971 (2020), https://doi.org/10.1088/1757-899X/971/2/022003.

[4] Sanchez Ramirez A., Islán Marcos M.E., Blaya Haro F., D'Amato R., Sant R., Porras J. "Application of FDM technology to reduce aerodynamic drag". Rapid Prototyp. J. 25 (2019): 781-791, https://doi.org/10.1108/RPJ-092018-0251.

[5] Yadav D.K., Srivastava R., Dev S. "Design \& fabrication of ABS part by FDM for automobile application". Mater. Today Proc. 26 (2019): 2089-2093, https://doi. org/10.1016/J.MATPR.2020.02.451.

[6] Samykano M., Selvamani S.K., Kadirgama K., Ngui W.K. Kanagaraj G., Sudhakar K. "Mechanical property of FDM printed ABS: influence of printing parameters". Int. J. Adv. Manuf. Technol. 102 (2019): 2779-2796, https:// doi.org/10.1007/S00170-019-03313-0.

[7] Cantrell J.T., Rohde S., Damiani D., Gurnani R., DiSandro L., Anton J., Young A., Jerez A., Steinbach D., Kroese C., et al. "Experimental characterization of the mechanical properties of 3D-printed ABS and polycarbonate parts". Rapid Prototyp. J. 23 (2017): 811-824, https://doi. org/10.1108/RPJ-03-2016-0042.

[8] Rajesh N., Guru Mahesh G., Venkataramaiah P. "Study of Machining Parameters on Tensile strength and Surface roughness of ABS samples printed by FDM". Adv. Mater. Process. Technol. (2021), https://doi.org/10.1080/2374 068X.2021.1946758.

[9] Wichniarek R., Hamrol A., Kuczko W., Górski F., Rogalewicz M. "ABS filament moisture compensation possibilities in the FDM process. CIRP J. Manuf. Sci. Technol. 35 (2021): 550-559, https://doi.org/10.1016/J.CIRPJ.2021.08.011.

[10] Wu W., Geng P., Li G., Zhao D., Zhang H., Zhao J. "Influence of layer thickness and raster angle on the mechanical properties of 3D-printed PEEK and a comparative mechanical study between PEEK and ABS". Materials (Basel). 8 (2015): 5834-5846, https://doi.org/10.3390/ MA8095271.

[11] Kozior T. "Rheological properties of polyamide pa 2200 in sls technology". Teh. Vjesn. 27 (2020): 1092-1100, https://doi.org/10.17559/TV-20190225122204.

[12] Bochnia J., Blasiak S. "Stress relaxation and creep of a polymer-aluminum composite produced through selective laser sintering". Polymers (Basel). 12 (2020), https://doi.org/10.3390/POLYM12040830.

[13] Mohamed O.A., Masood S.H., Bhowmik J.L. “Optimization of fused deposition modeling process parameters: a review of current research and future prospects". Adv. Manuf. 3 (2015): 42-53, https://doi.org/10.1007/ S40436-014-0097-7.

[14] Gebisa A.W., Lemu H.G. "Investigating effects of Fuseddeposition modeling (FDM) processing parameters on flexural properties of ULTEM 9085 using designed experiment". Materials (Basel). 11 (2018), https://doi org/10.3390/MA11040500.

[15] Bochnia J. Wybrane właściwości fizyczne materiałów kształtowanych technologiami przyrostowymi (in English - Selected physical properties of materials obtained with additive technologies), (2018), ISBN 978-83-65719-36-2. 